\title{
Children Safety: Education Game for Child's Sex Education
}

\author{
FajarAs'ari \\ Department of Information Systems, Faculty of Computer Science \\ Soegijapranata Catholic University (SCU), Semarang, Indonesia \\ asari.fajar@gmail.com \\ Fx. HendraPrasetya, ST., MT \\ Department of Information Systems, Faculty of Computer Science \\ Soegijapranata Catholic University (SCU), Semarang, Indonesia \\ ridwan@unika.ac.id \\ Dr. RidwanSanjaya \\ Department of Information Systems, Faculty of Computer Science \\ Soegijapranata Catholic University (SCU), Semarang, Indonesia \\ ridwan@unika.ac.id
}

\begin{abstract}
Some people still cannot talk freely about sex education. On the other hand, some of them have an assumption that teaching sex education will leads to free sex behavior. Sometimes parents are afraid to talk about sex education with their children, even some parents think that sex education is not important for children.

In fact, children need to know about sex education for their own good. To children, sex education is to explain differences between male and female and to know well about themselves. Creating media to deliver sex education is the way to teach children about sex education. Among many media, game is one option to deliver this education.

This research will discuss game for child's sex media education. The reason for using game as media for sex education is that game has capability to deliver message. Through game concept of picture and animation, game delivers sex education to children with the objective to prevent the child from sexual abuse. However, when the children play the game they need to be guided and accompanied by adults to make sure that children understand the meaning of game message through game story.
\end{abstract}

Keywords: game, game education, sex education, sex education game, child's sex education.

\section{INTRODUCTION}

Sex education; some pe ople a re unfamiliar with this term. S ome of $\mathrm{t}$ hem feel awkward and $t$ he ot hers feel af raid, especially pa rents who $\mathrm{c}$ annot s peak fre ely with $\mathrm{t}$ heir $\mathrm{c}$ hildren about s exuality. Parents have an assumption that talking abouts ex educ ation means talking about s ex $\mathrm{t}$ oo, a nd $\mathrm{s}$ ex is just for adult[1].

Indeed, sex education also teaches about sexuality but $\mathrm{s}$ ex education also teaches another a spect like $\mathrm{m}$ oral as pect, social behavior, law, until culture, according $\mathrm{t} o$ Ulwan [2]. In addition, Sarwono added that sex education could be a pr eventive way to keep away $f$ rom $t$ he ne gative ef fects of $s$ ex deviation[2].Sex education for children itself is to introduce children about gender and how to take care of it[3]. Child's sex education can be delivered to children when the children are in playgroup (3-4 years old). This is intended to give explanation to children about similarities and differences between female and male so in the end, children know a bout themselves, a $\mathrm{s}$ stated by Dr. Rose Mini AP., M.Psi [2].

Sex education can also be delivered through game. A research developed by Applied Research $\mathrm{C}$ enter $\mathrm{f}$ or $\mathrm{H}$ ealth \& Lifestyle and intended for $\mathrm{t}$ eenagers discusses about prototype of a game which materials are about reproduction, prop er bi rth control, and also sexuallyt ransmitted infection (STI) [4]. Another re search discusses sex education that 
can be ada pted into a $g$ ame $\mathrm{t} o$ introduce differences between male and female[3].

Children Safety Game is one of $t$ he $g$ ames that adapt sex education material intended for children. This $g$ ame $t$ eaches children $t o$ anticipate $\mathrm{s}$ exual abus $\mathrm{e}$. This $\mathrm{g}$ ame has five stages to deliver educ ation about chi ld's s ex abuse anticipation and hree information support in game story. Survey has been done to thirty pe oples who have already kno wn sex education to evaluate materials on the game by playing Children Safety.

\section{LITERATURE REVIEW \\ 2.1 Education Game}

Game is an organized and structured rule to create a room which can be enjoyed by adults who play the game too. Video game itself is a player experiences that is described in a game character. On the other hand, video game can give 1 esson. T hrough de livering some i ssue then player will catch the information from the issue while playing a game[5].

Education game de livers an information to enrich knowledge and support learning process through interactive media[6]. Game is a b ridge to know t he f act, correlate i dea, or he $\mathrm{lp}$ relating $t$ wo di fferent know ledge[5]. To motivate and create i nterest on learning ar e education game $\mathrm{b}$ enefit, according $\mathrm{P}$ ivce and Koubeck[6].

\subsection{Children Safety Game}

Children Safety is a game that is intended to anticipate child sexual abuse and this game is in Indonesian. When $\mathrm{c}$ hildren $\mathrm{pl}$ ay the $\mathrm{g}$ ame they ne ed a companion to expl ain $\mathrm{t}$ he information which is hard to be understood by children. Five games tages begin by introducing $f$ amily $\mathrm{m}$ embers, differentiating between male and female, simulation story when a child's pr ivate organ is touched by another pe rson, then simulation s tory when a child meets a stranger, and the last stage is a simulation story when a child meets someone who has already known by the children. Three information is also a dded to s upport t he information delivered through the game story.

Children Safety Game is intended to children grade 1-3 elementary school with sex education materials $t$ hat ha ve be en adjusted. To a void children misunderstandings when interpreting the $\mathrm{s}$ tory or $\mathrm{i}$ nformation i $\mathrm{n} t$ he game story, children need a companion.

\subsubsection{Game Start}

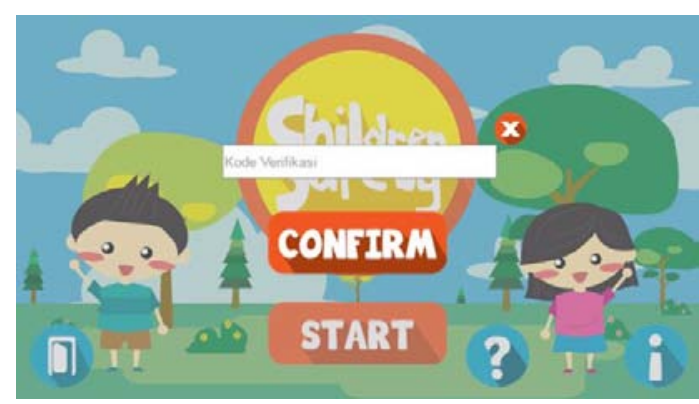

Fig 2. 1 Start Menu in Children Safety Game

On game s tart, player ne eds verification code t o g o to stage menu. Verification code should only be known by the companion.

\subsubsection{Game Stage}

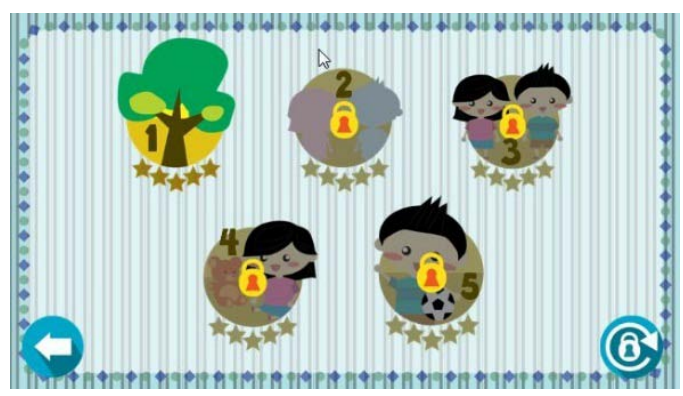

Fig 2. 2 Stage Menu in Children Safety Game

In game s tage menu, there are five stages. Stage $\mathrm{t}$ wo until $\mathrm{f}$ ive ar e 1 ocked; to ope $\mathrm{n}$ it a player $\mathrm{s}$ hould $\mathrm{pl}$ ay previous $\mathrm{s}$ tage. For example, to open stage two a player s hould play and finish stage 1 ; to open stage three a player should play and finish stage two, and so on. 

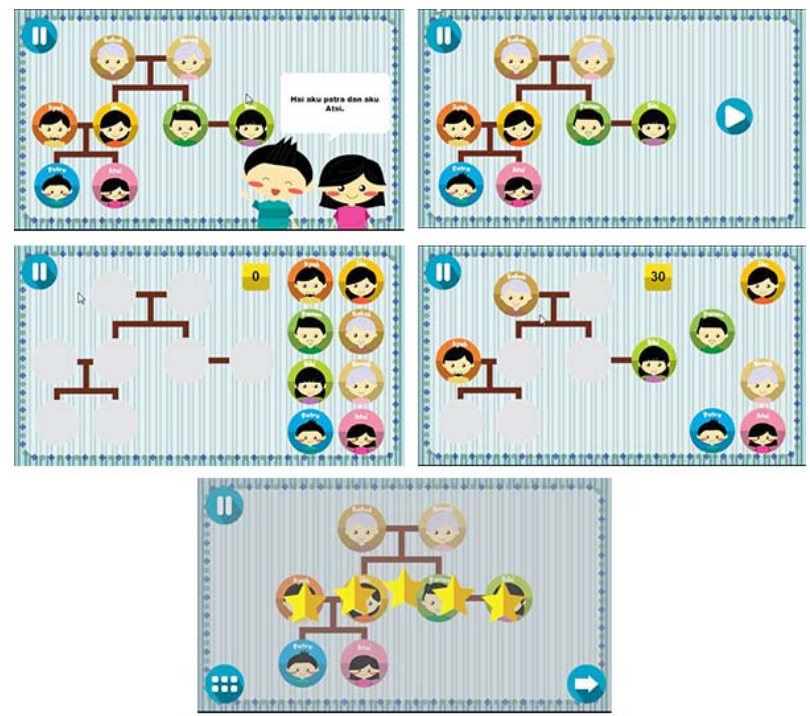

Fig 2. 3 Stage 1 Children Safety Game

Arranging family tree from game Chi ldren Safety cha racter, Patra and Atsi. This puz zle game is intended t o t each chi ldren to know who Patra and Atsi family m embers are. So when playing anot her s tage, a player know s who Patra and Atsi family members are, and who are not family members.

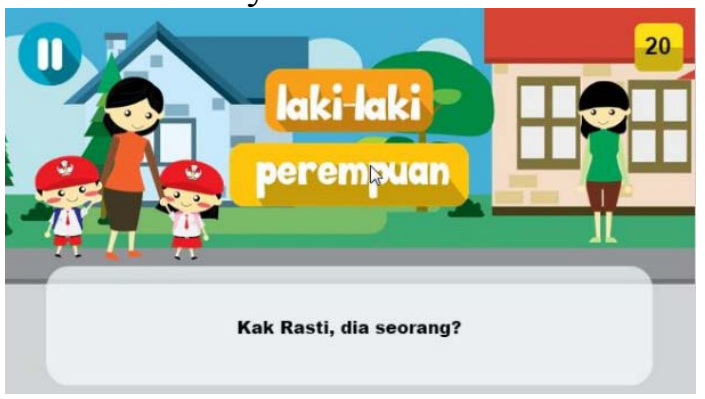

Fig 2.4(a) Stage 2 Children Safety Game (1)

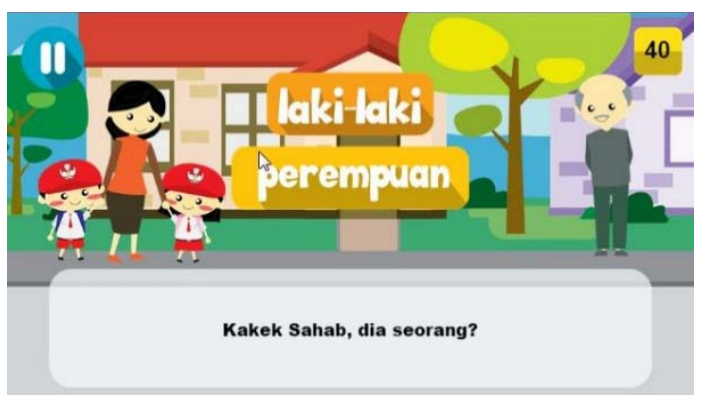

Fig 2. 4(b) Stage 2 Children Safety Game (2)

Stage 2 is when Patra and Atsi are going to school and meeting many people on their way.
Then they categorize people they meet by male or female. In this stage, the player or children are asked for di fferentiate a $g$ ender $b$ y appearance; be side app earance text on dialog box c an be a hint to know whether this N PC male or female.

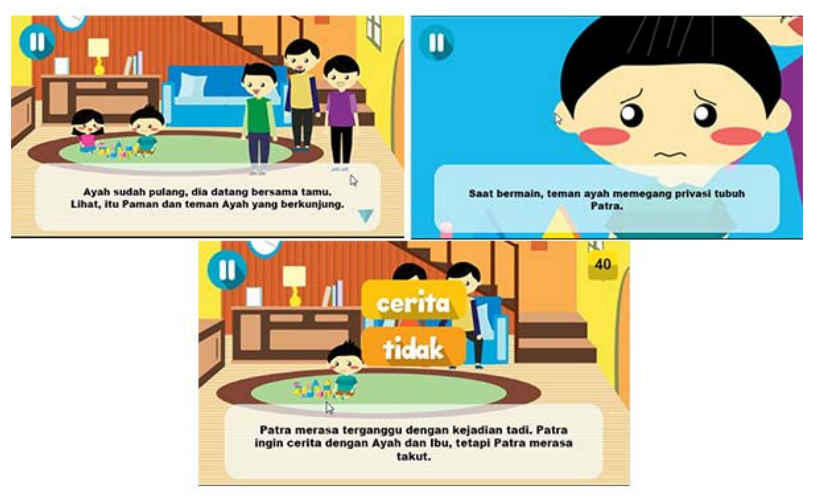

Fig 2. 5 Stage 3 Children Safety Game

Stage three, simulation story when another person touches Patra's private organ and this person asks Patra to keep this as a secret. Then Patra $f$ eels uncomfortable and a fraid, a nd a button with options whether to tell about what happened or not appears. This game stage is to teach player es pecially chi ldren to tell their secret to their parents, especially a secret that makes them worried.

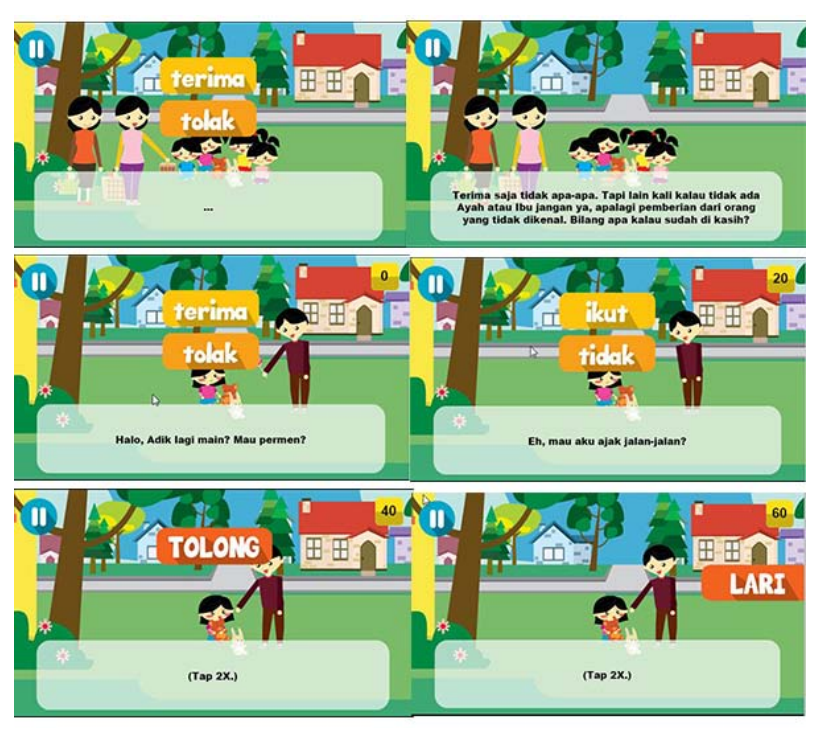

Fig 2. 6 Stage 4 Game Children Safety 
On the stage 4, Atsi is playing outside with her fri ends. A tsi $\mathrm{m}$ eets two people, A unt Amaand is a stranger. When she meets Aunt Ama, she gives Atsi a cake and her mother is around there. Then a button comes up with an option "terima" as accept or "tolak" as reject. If the children choose " tolak" $t$ here $i \mathrm{~s}$ an explanation, $w$ hen the parents are around the children and someone gives something such as, candy, cake, etc. the children c an take i t. However, if the parents a re not a round them, children should not take it, even if the one who gives it is s omeone $\mathrm{w}$ hom the children have already known.

Atsi al so m eets a stranger $w$ ho gives her candy a nd a sks Atsi t o g o out. Chi ldren w ill choose the button to accept or reject everything that a stranger asks. If the children choose the button to a ccept, an explanation will show up that children should $r$ eject $t$ he a llurement. In the story line, the stranger will force Atsi to go out then o $n$ the s creen a button "tolong" to shout he lp will app ear then a button "lari" to look for help will also appear.

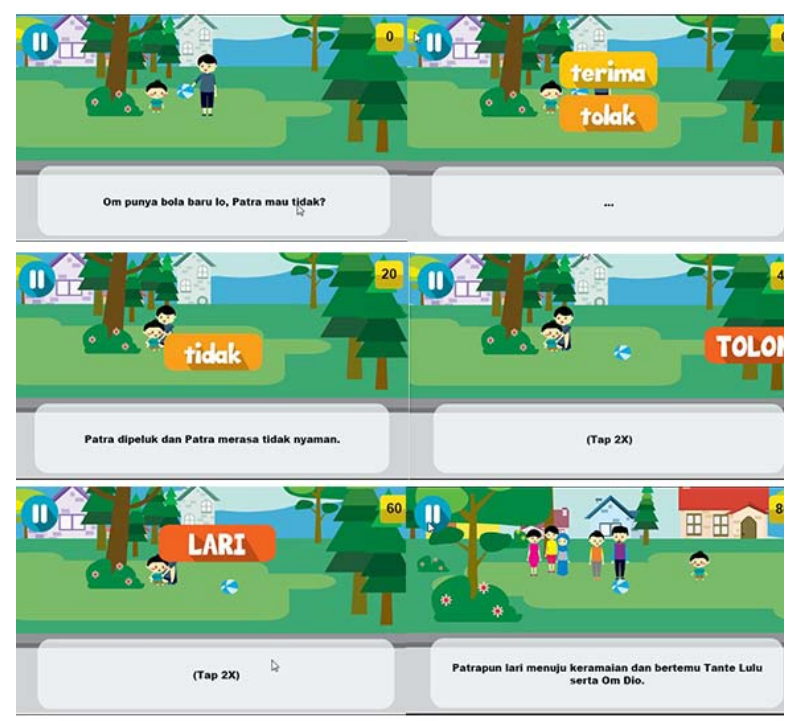

Fig 2. 7 Stage 5 Game Children Safety

Stage 5 has the same pattern as stage 4 , the differences are on the potential offenders who are the people $\mathrm{w}$ hom children have already known. In this stage, setting of story is in the park where Patra is playing. The offe nder is someone who is called uncle by Patra. In the story, the uncle gives Patra a ball then a button to choose "a ccept" or "r eject" appears. Then uncle and Patra talks together, and Patra gets a hug which makes $\mathrm{P}$ atra f eels uncomfortable. After that buttons of button "tolong" and "lari" will appear on the screen as in stage 4 .

\subsubsection{Menu Info}

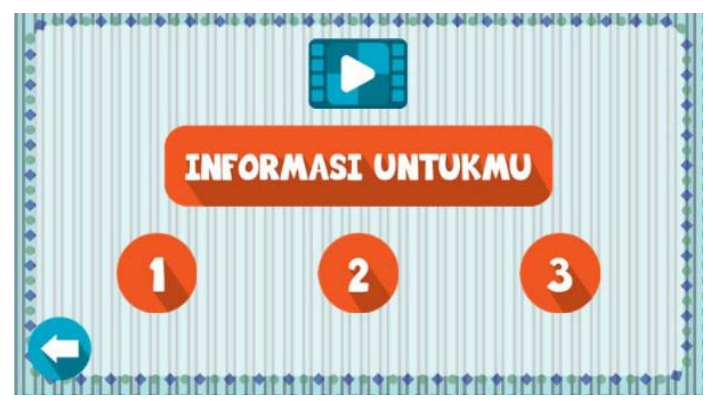

Fig 2. 8 Menu Info Game Children Safety

Info Menu is cr eated to s upport the information that is delivered through the game story.

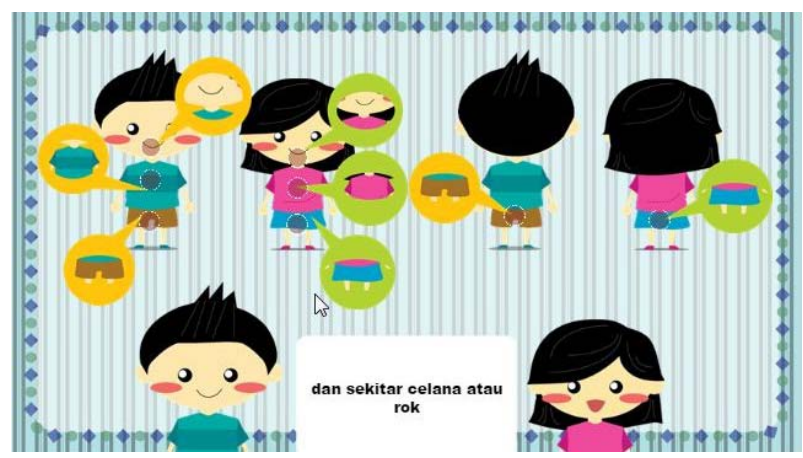

Fig 2. 9 Info 1 Children Safety Game

The first info is about child's private organs that the other should not be allowed to touch. They are mouth, chest, and areas around pants or s kirt. A round the pants or s kirt are crotch and butt described by picture[7][8]. 


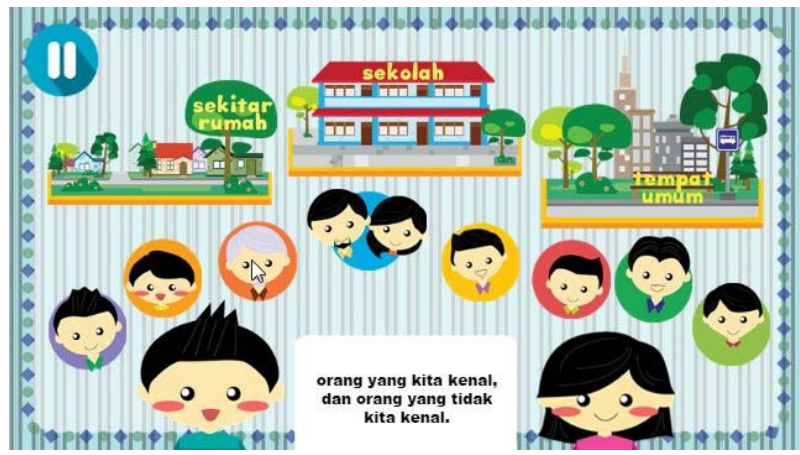

Fig 2. 10 Info 2 Children Safety Game

The second info explains the places where sexual abuse could happen, such as around the house, s chool, a nd publ ic pl aces. It also explains that nobody cannot force children to do something $\mathrm{t}$ hat $\mathrm{m}$ akes chi ldren feel uncomfortable, ev en if that someone is a person whom the children love or know[7][8].

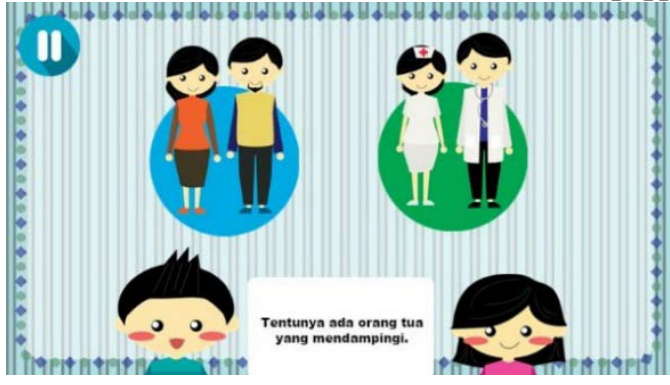

Fig 2.11(a) Info 3 Children Safety Game (1)

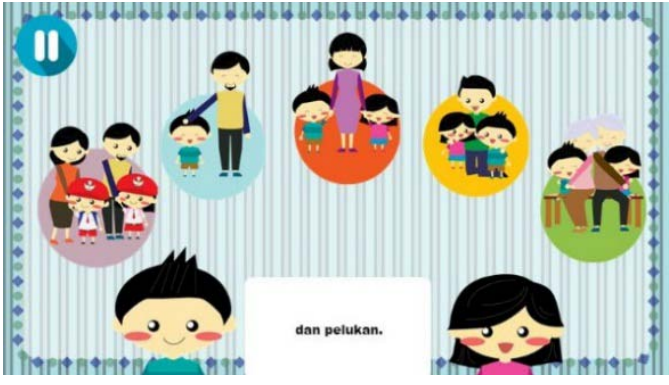

Fig 2. 11(b) Info 3 Children Safety Game (2)

The third i nfo is about the ev ents when someone can touch child's private organ. For example, when a doctor examines children and the parents accompany them. Also, this i nfo explains safe $t$ ouch for children like handshake, stroked the head, coupled, embrace or hug.

\section{RESEARCH METHODOLOGY}

Distributing questionnaire form into 30 respondents to s urvey Children Safety game has already be done. $\mathrm{B}$ efore the respondent fills the form, they have to play the game first. Respondents are those who have already known sex education or child's sex education.

\section{RESULTS AND DISCUSSION}

The r esult of the questionnaires distributed into 30 respondent is described in bar charts.

How hard to play game Children Safety?

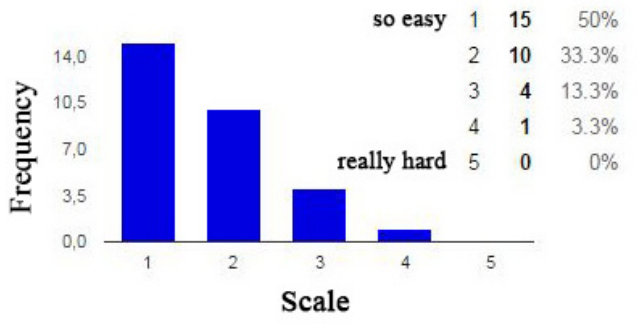

Fig 4. 1 Difficulty to play Children Safety.

Are you agree if game Children Safety as a media to deliver sex education?

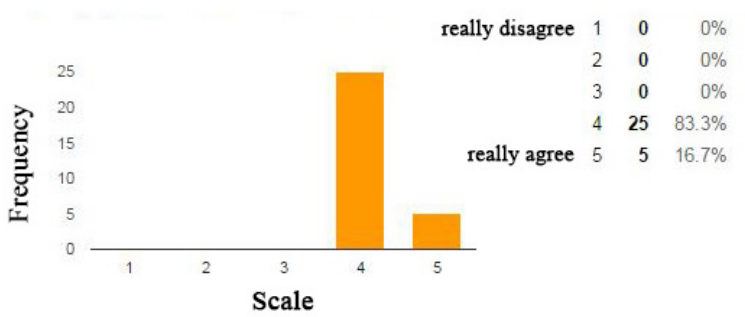

Fig 4. 2 Children Safety as a sex medium education.

As a sex media education, is it the material of sex education on game Children Safety relevant for child's sex education?

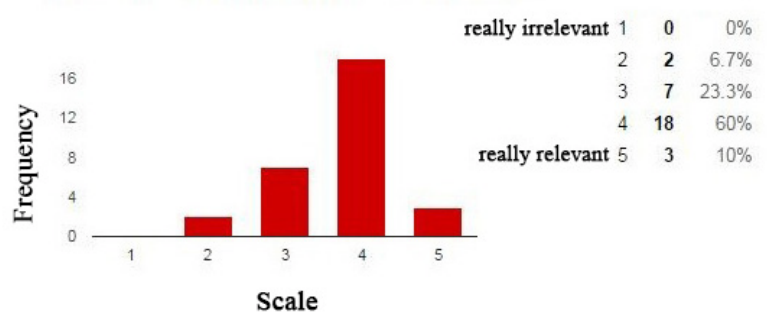

Fig 4.3 Children Safety is a satisfactorily sex education material. 


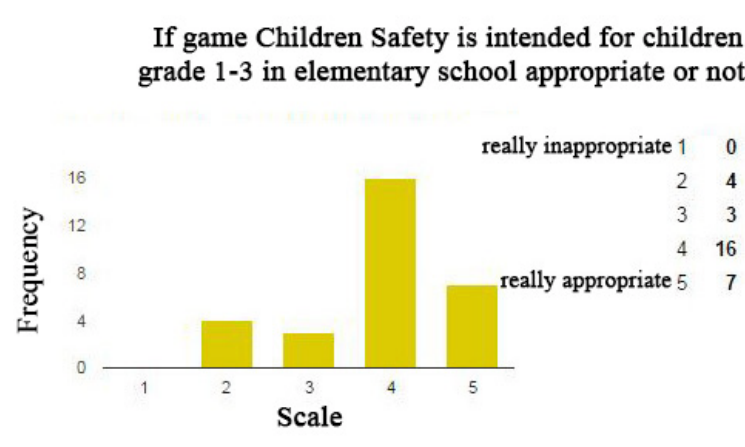

Fig 4.4 Children Safety is appropriate for children grade 1-3 in elementary school.

From the s urvey, the re spondents' opi nion on Children Safety game as an education game can be summarized as follows:

- The game i s eas y t o be played by adult, someone w ho will accompany chi ldren to help or teach children how to play the game.

- Children Safety game can be a m edia to teach child's sex education.

- Sex education $m$ aterials on the game a re relevant to teach child's sex education.

- The game can be sex media educ ation for children grade 1-3 in elementary school.

Some respondents stated that the materials of c hild's s ex e ducation have a de ficiency in the way the game shows human genital organs The game just shows where the genital organ is implicitly b y s howing the pa rt of $t$ he bod $y$ where $t$ he or gan is 1 ocated. $T$ his ha ppened because not all parents are ready to show the genital organ explicitly ev en through sketch picture to their children.

\section{CONCLUSION}

Game can deliver information and become a medium of education as in an education game. Sexual educ ation is on e of the education that could be adapted into education game. One of the education games with the topic of sex education is Children Safety game.

Overall, Children Safety game can be a tool to help deliver sex education for children. Sex education materials are also relevant for sex education especially child's sex education. To adjust the game $\mathrm{w}$ ith public $\mathrm{r}$ eadiness, summarizing the material about sex education has done. It makes some respondents give their opinion that the $\mathrm{m}$ aterial have a de ficiency from sex education perspective.

\section{ACKNOWLEDGEMENT}

FajarAs'ari is a Game Technology s tudent in SoegijapranataCatholic University. Based on his academic excellence, he receives scholarship from the Ministry of $\mathrm{N}$ ational Education of Re public I ndonesia (BeasiswaUnggulanKemendikbud RI)

\section{REFERENCES}

[1] J. Frankham, "Sexualities Sexual Antimonies and Parent / Child Sex Education : Learning from Foreclosure," J. Sex., vol. 9, no. 2, pp. 236-254, 2006.

[2] D. A. Fajar, Susanto, and R. Achmadi, "Strategi Optimalisasi Peran Pendidikan Seks Usia Dini di Paud Dalam Menanggulangi Pelecehan Seks Terhadap Anak di Pekalongan," J. LITBANG, vol. 13, pp. 40-52, 2014.

[3] A. P. Rilianti and A. Ima, "Play Study: Educational Game Sebagai Media Belajar Pendidikan Seks Bagi Anak Sekolah Dasar," Pelita - Jurnal Penelitian Mahasiswa UNY, 2011. [Online]. Available: http://journal.uny.ac.id/index.php/pelita/ article/download/4275/3700. [Accessed: 22-Jul-2016].

[4] J. L. Vogel, "Prototype of an Educational Video Game for Knowledge Retention in Youth Health Education Jennifer L. Vogel University of Central Florida," in Proceedings of the Human Factors and Ergonomics Society 58th Annual Meeting, 2014, pp. 1944-1948.

[5] L. Botturi and C. S. Loh, Games : Purpose and Potential in Education, 1st ed. USA, New York: Springer Publishing Company, Inc., 2008.

[6] V. W. Febriani, D. S. Ardityo, and R. Sanjaya, "Idea Development on Games of Education for School' $\mathrm{s}$ 
Entrepreneurship Sustainability," J. Int. Conf. eLearning Knowledge-Based Soc., vol. 19, no. 11, 2014.

[7] UNICEF, "Kisah Aksa," YouTube, 2014. [Online]. Available:

https://www.youtube.com/watch?v=zAk EXUbjtKY. [Accessed: 19-Jun-2016].

[8] UNICEF, “Kisah Geni," YouTube, 2014. [Online]. Available:

https://www.youtube.com/watch?v=5e

M1U6PXyZk. [Accessed: 19-Jun-2016].
[9] NSPCC, "Simple Conversations to Keep Your Child Safe From Abuse."

[Online]. Available:

http://www.nspcc.org.uk/preventingabuse/keeping-children-safe/underwearrule/. [Accessed: 10-Apr-2015]. 